\title{
Effect on surface deformation resulting from mining activity on value of property valuation. A case study from Jastrzębie- Zdrój region
}

\author{
Paweł Pala
}

Faculty of Earth Sciences, University of Silesia, Będzińska Str. 60, 41-200 Sosnowiec, Corresponding author: pawel.palla@gmail.com

Received: $4^{\text {th }}$ June, 2018

Accepted: $12^{\text {th }}$ June, 2018

\begin{abstract}
The subject of the research presented in this article is the effect of subsidence resulting from underground mining exploitation on the value of non-developed real estate intended for residential construction (excluding multifamily) in Jastrzębie-Zdrój region. The article describes methodology, which helped in creating a map of average unit prices of non-developed residential properties and a map of subsidence in years 2008-2017, as well as a chart comparing these two issues. The results of the research show a relation between subsidence and nondeveloped residential properties value.
\end{abstract}

Key words: mining, subsidence, property value

\section{Introduction}

Mining activity is one of the most significant human interference in widely understood environment, which results in adverse changes in the environment. In Poland, the greatest environmental changes are due to hard coal extraction and they are far more diverse than in case of other minerals. Moreover, different surface movements can be observed in this area and these movements differ in intensity and duration, and long-term subsidence can be observed many years after termination of minerals' extraction (Wojciechowski, 2007; Dubiński and Mutke, 1992).

Subsidence resulting from mining activity lead to hydrological and hydrogeological changes, but most importantly to destruction of on-surface building objects. On the areas affected by mining activity, the degree and type of activity influences properties and consequently property value. Underground exploitation makes usage of significantly more difficult, while opencast mining prevents completely consideration of land as building land (Kaszowska, 2007).

\section{Description of the area}

From the administrative perspective the researched area is located in Silesia Voivodeship and the study area covers the city of Jastrzębie-Zdrój with communes: Pawłowice, Mszana, Świerklany.

The analyzed area, from geomorphological perspective, is located on the south side of the Rybnik Plateau, which is a part of the Silesian Upland macro-region. The study area is in its entirety within the area of well-developed Upper Oder river basin and it is characterized by hilly area of the latitudinal course, rising from $233 \mathrm{~m}$ a.s.1. but it does not exceed $290 \mathrm{~m}$ a.s.1.

The Rybnik Plateau is built up of brown and dust soil, that were created from dust, dustargillaceous and loess-like sediment, as well as from clay crusts (soil and agricultural map of Poland - map prepared on the basis of a geological map of Poland 1: 200,000 by 
members of the staff of the University of Silesia for the purposes of an ecophysiographic study for the area development plan for the Silesian Voivodeship 2003). The substrate of this area is built of Carboniferous rocks with hard coal deposits, on which sediments containing salt, gypsum and sulfur deposits are located.

Region of the Southern-East part of Upper Silesia Coal Basin is covered by mines belonging to Jastrzębska Spółka Węglowa S.A., which operates within hard coal seams of Carboniferous. The research concerns majority of the area of the mining area of "BoryniaZofiówka-Jastrzębie" and "Pniówek" hard coal mines. "Borynia-Zofiówka-Jastrzębie" consists of: Borynia Mine $-17.4 \mathrm{~km}^{2}$, Zofiówka Mine $26.8 \mathrm{~km}^{2}$, Jas-Mos Mine - $32.5 \mathrm{~km}^{2}$. And "Pniówek" Mine covers only $28.5 \mathrm{~km}^{2}$. The mines started operations in the second half of the $20^{\text {th }}$ century (the oldest "Borynia" mine started extraction in 1972) and continue operations until today (Website: https://www.jsw.pl/).

\section{Methodology and findings}

The studies were carried out from January 2008 to December 2017. The scope of the conducted research has been divided into three main parts:

- Preparation of a map of subsidence contour lines,

- Preparation of a map of average unit prices of non-developed residential properties,

- Preparation of a comparative chart and analysis of the results

Vector maps of the analyzed area in AutoCAD format (dwg) for the years: 2008 2010, 2011 - 2013, 2014 - 2016, 2017 - 2018 were gained from Jastrzębska Spółka Węglowa S.A. The materials included diverse information, thus, only relevant data was extracted i.e., contour lines of subsidence. In order to continue analysis in a different software, all the points creating the contour lines were saved in a text format (txt - in the format: $x, y$, value of the contour line). It is worth to remember that what for geodetic equipment (and AutoCAD software) is an $\mathrm{x}$ value, for GIS is a y value and this must have been reflected in further research. Maps of subsidence were created in Quantum GIS ("QGIS") with an extension Contour.

The first step of the data development was data interpolation in pairs, using the inverse distance method ("IDW"). The merger of the contour-lines of the first time period with the second was done, and then its result was merged with the third time period etc. The result is a contour-line map for the researched time period, i.e. January 2008 to December 2017. The contour-lines are connecting points of the same subsidence values and are expressed in meters. Then, for the point map, contour lines with unusual gradation were generated. The values of the contour lines were expressed in meters and are presented chronologically: 0.1, 0.5, 1.0, 2.0, 3.0, 4.0, 5.0, which enabled detailed visualization and precise further calculations. The next step is the right choice of colors and using them to fill the contour lines. A map prepared in such a way shows distribution of subsidence for the analyzed area (Fig.1).

The available database collected by the Institute of Real Estate Market Monitoring and Analysis covered all available records regarding purchase and sale of undeveloped land in the area covered by the analysis in the period from 01/01/2008 to 21/12/2017 (Fig.2).

From the base thus created, these quotations were selected with lands that were located in areas designated for housing (i.e. single-family housing, housing \& services and mixed housing, also with fragments intended for roads). Whereas land for multi-family housing was excluded from the analysis, as such lands usually achieve significantly higher unit prices due to the developer's greater profit opportunities and their significantly limited supply. The quotations were also removed, which significantly deviated from the average prices obtained on the market, and quotes for which there was a justified suspicion that they do not meet the conditions necessary to recognize the transaction as free market and those that do not have the quality of a building plot. 


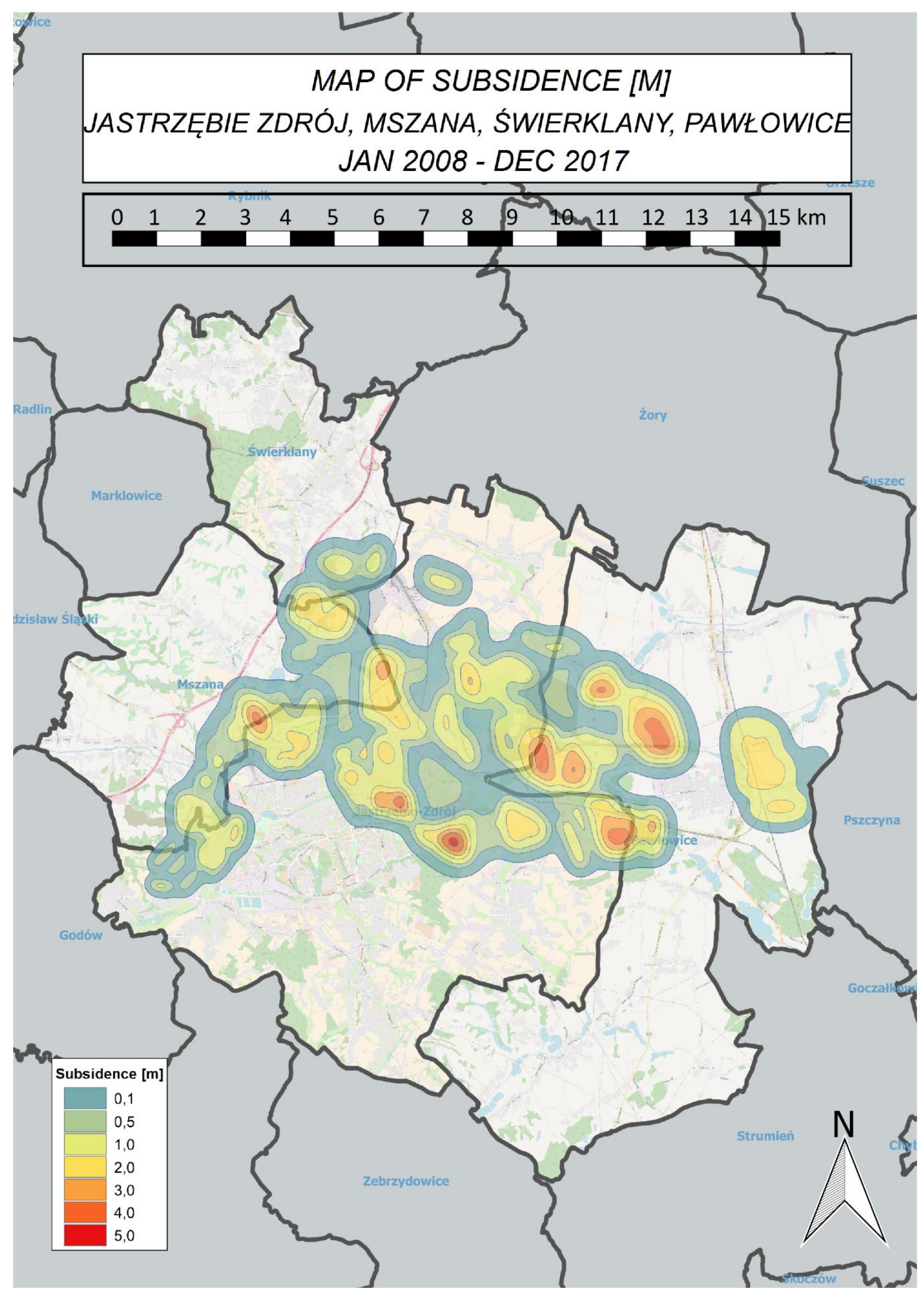

Fig.1. Map of contour lines of subsidence in 2008-2017 


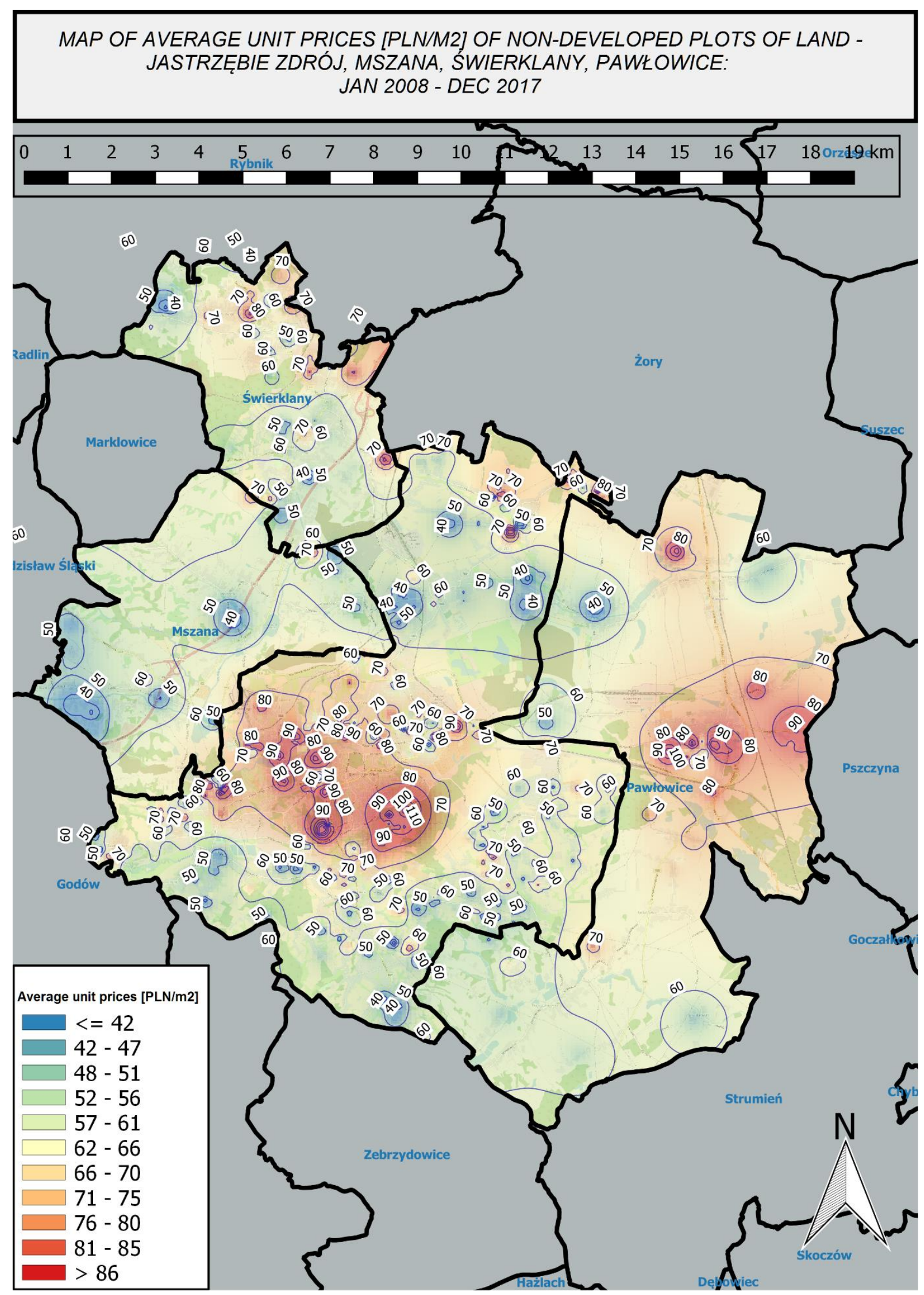

Fig.2. Map of average unit prices of non-developed residential properties 
1008 transactions, covering plots with areas ranging from $350 \mathrm{~m}^{2}$ to $2000 \mathrm{~m}^{2}$, were used for the final analysis.

The map of real estate prices was made using the inverse distance method ("IDW"), which is based on the assumption that the price value at a given point depends on the price in the nearest (neighboring) points.

The geo-tagged data was entered in the QGIS application and on their basis interpolation was performed using the inverse distance method. This method divides the area under study into a given number of cells and calculates the value for each cell based on the value of neighbor points, weighted by the inverse of their distance. As a result, the further away is the point, the smaller its influence on the interpolated value. Next, on the basis of the map created in this way, contour lines were generated for the studied region every 10 PLN.

The Institute of Real Estate Market Monitoring and Analysis has made a map of average real estate prices (non-developed land with residential purposes), which illustrates, by means of contour lines, the geographical distribution of average property prices.

Analyzes and interpretations of the impact of the dependence of unit land prices and subsidence were made using the linear regression method (Fig.3). Based on the constructed model, a negative correlation was noticed. This means that with the increase in the value of subsidence in this area, the average unit price for undeveloped residential properties drops.

Additionally, the chart (Fig.3) was enriched with columns representing the average price value for a given subsidence value. To create such a graph, the information about the land area occupied, each property and the value of the price in this area was used. Surfaces in $\mathrm{m}^{2}$ were calculated and read from previously created maps in the QGIS program - using the field calculator in the attribute table. By assigning the area to a given settlement value and the average unit price of the land, it was possible to calculate the arithmetic weighted average of unit price (non-developed residential properties) for each subsidence value where weights are values of the area expressed in $\mathrm{m}^{2}$.

The chart omits subsidence of $0.1 \mathrm{~m}$, due to the small significance of this size in comparison with other subsidence of land occurring in this region.

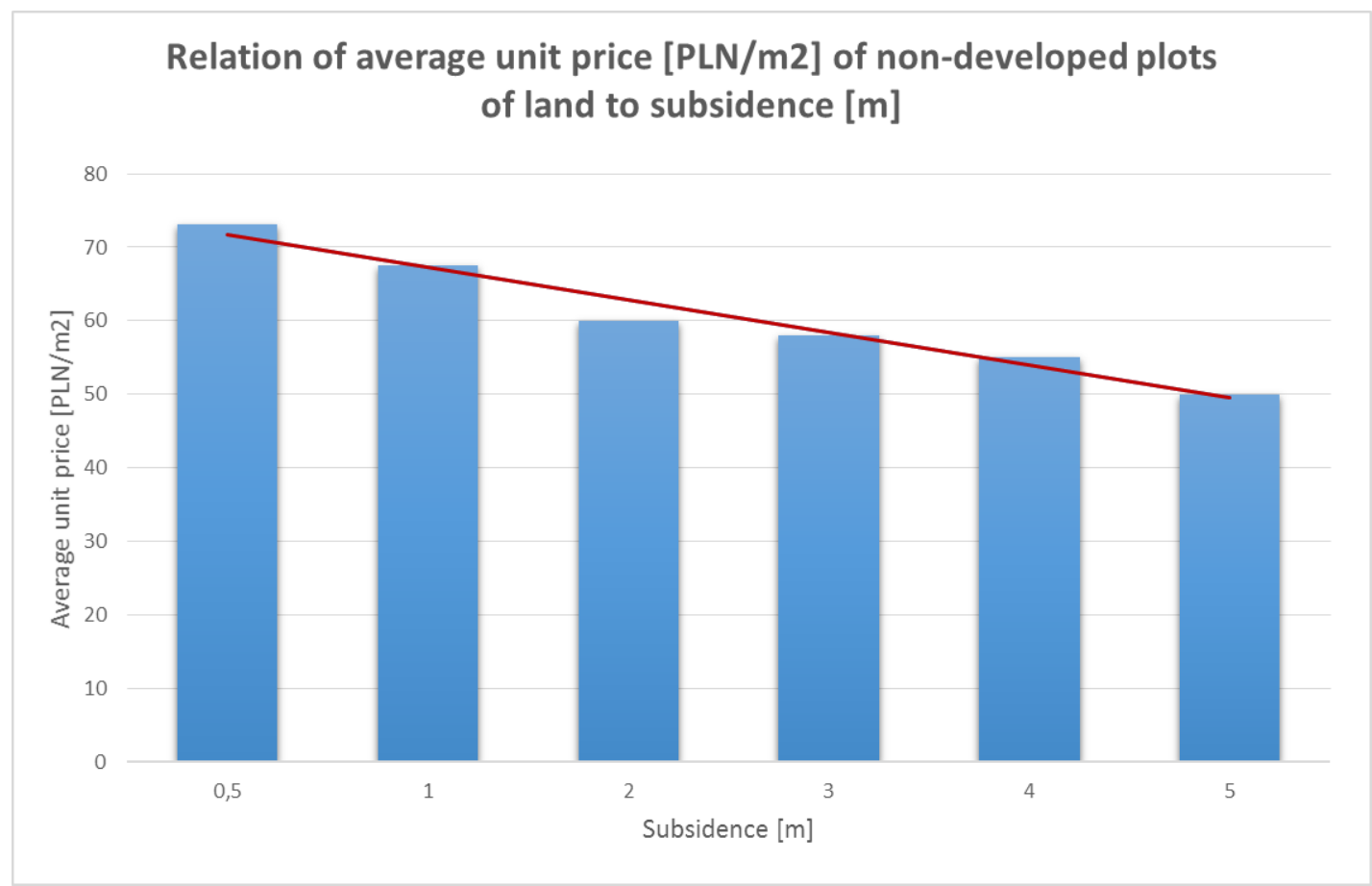

Fig.3. Relation of average unit price of non-developed plots of land to subsidence 


\section{Summary and conclusions}

The article presents the stages of work on the creation of cartographic visualization in the form of maps in two thematic areas: the average unit price of undeveloped residential properties and subsidence in 2008-2017, as well as a chart comparing these two issues.

The presented results were developed using the GIS methods where they, in particular the process of obtaining and vectorizing data, are quite time-consuming. On the other hand, created cartographic visualizations can become the basis for further calculations and wider surveys. The GIS software also gives the possibility of a diverse visualization of the obtained results.

Based on the above research, it was found what changes in subsidence occurred within 10 years. These changes mainly cover the area of coal mines and the area adjacent to them. Subsidence in this area are generally drops of 2 meters, but in some areas they reach up to 5 meters.

The obtained results show how strongly the subsidence of the area influences the market value of land. Mining deformations of the area may cause damage to buildings, which are not limited to structural elements, but also elements of finishing and equipment, which is why a very important element is to investigate property subsidence before its valuation. It is worth emphasizing, however, that subsidence is not the only factor affecting the valuation of real estate. There are many factors that can affect its value, they are divided into environmental and socio-economic values. Most often, the following factors have the greatest impact on the value of the land: location, condition of equipment in technical infrastructure, condition of development and soil class (Parzych, 2007; Zydroń and Walkowiak, 2013).

\section{References}

Dubiński J., Mutke G. (1992) The impact of mining rock mass shocks on the surface. Materials of the Underground Mining School. CPPGSMiE PAN, Kraków

Kaszowska O. (2007) The impact of underground mining exploitation on the surface of the area, Problems of Ecology 1

Parzych P. (2007) Modeling the value of urban real estate. Studies and Materials of the Scientific Society of Real Estate 15, 3-4

Zydroń A., Walkowiak R. (2013) Analysis of attributes affecting the value of undeveloped property designed for construction purposes in the Mosina commune. Annual Set The Environment Protection. edition XV

Wojciechowski T. (2007) Subsidence of land surface under the influence of hard coal mining on the example of the area of the town of Knurów. Przegląd Geologiczny 7, 589-594

Institute of Real Estate Market Monitoring and Analysis (Website: accessed 26th April, 2018 www.https://imars.pl/)

Jastrzębska Spółka Węglowa S.A. (Website: accessed 5th May, 2018 https://www.jsw.pl/)

The soil and agricultural map of Poland (Website: accessed 5th May, 2018 http://mapy.orsip.pl/imap/) 